\section{Financial Policies in Socialist Countries in Transition}

Boris Pleskovic
WPS 1242

1242

Most transitional economies

have adopted a gradual approach to reform of their

financial systems, maintaining the banking system's passive role. But the financial restructuring of banks and enterprises should be undertaken simultaneousty early in the transition.

The World Bank

Research Advisory Staff

Office of the Vice President, Development Economics January 1994 


\section{Summary findings}

One legacy of central planning, says Pleskovic, is that the financial systems in the transitional economies are even less developed than in many developing countries. He contends that the main goal of financial reform in these economies should be to make passive financial systems active - to make financial systems participate actively in the economy, as they do in market economies.

For this to happen, the :ransitional economies must develop banking systerts that allocate credit efficiently. Commercial banks must screen borrowers and monitor and discipline enterprises. The role of the government or the central bank should be limited to regulation and supervision.

Most transitional economies have adopted a gradual approach to reforming their financial systems, maintaining the banking system's passive role. But banking reform in Eastern Europe cannot wait for enterprise restructuring and privatization, because both banks and state enterpriser are burdened with inherited bad debts that endanger their solvency and hence that of the economy.

The financial restructuring of banks and enterprises should be undertaken simultancously, says P! iskovic, and should start early in the transition. Commercial banks should play an active role in the financial restructuring of enterprises. Governments must take responsibility (through the budget) tor the debts of nonviabie enterprises in a transparent manner and for the recapitalization of banks after their clecilup. Otherwise the healthy segments of the commercial sectors will have to carry the burden of financial restructuring, which wil! slow down the transition.

Farly in the transition, attet.tion must also be paid to improving the sy'stem of payments, demonopolizing banking, changing the structure of ov nership (including privatization), and intioducing n!arket-based financial legislation.

The speed of financial reform will depend greatly on the availability of skilled banking professionals, on access to technical assistance from abroad, fiscal constraints, and of course on specific country circumstances. For example, for most countries of the former Soviet Union - except for the Baltic states - a prerequisite to successful financial restructuring is macroeconomic stabilization and the reduction of high inflation rates.

The most important lesson from countries further alony in reform is that financial reform should not be delayed but should stant as soon as possible. Delays reciuce living standards (burdening the healthy parts of the economy with direct taxes or high financial costs), discourage small-scale entrepreneurs, inhibit the entry of new firms, and cause the coonomy to stagnate further.

This paper-a product of the Research Advisory Staff, Office of the Vice Presideni, Development Fconomies - is part of a larger effort in the Bank to investigate the transition of ecunumies of Eastern Europe and the former Soviet Union. Copies of the paper are available free from the World Bank, $1818 \mathrm{H}$ Street NW, Washington, DC 20433. Please contact Mani Jandu, room N9-037, extension 33103 (28 pages). January 1994.

The Policy Research Working Paper Series disseminates the findings of work in frogress to encourage the exchange of ideas about development issues. An objective of the series is 10 get the findings. ut quickly, even if the presentations are less than fully polis bed The papers carry the mames of the authors and should be ksed and ciled accordingly. The findings, interpretations, and conclusions are the ex: hors' own and should not be altributed to the World Bank, its Executive Board of Directors, or any of its member countries. 
FINANCIAL POLICIES IN SOCIALIST COUNTRIES IN TRANSITION

\author{
Boris Pleskovic \\ Research Advisory Staff \\ The World Bank \\ Washington, D.C. 20433 USA
}

The author wishes to thank Andres Bajuk, Joseph Bemik, F. Desmond McCarthy, Karen R. Polenske, Jeffrey D. Sachs, Philippa Shepherd, and Shahid Yusuf for their comments. All views expressed here are the author's own, and not necessarily those of the World Bank. Prepared for the symposium on the Market Economy and its Spiritual-Cultural Consequences in Formerly Communist Countries, Pontificio Instituto Orientale, Centro Studi e Richerche Ezio Aletti, Rome, Italy, October 3-7, 1993. 


\section{Introduction}

The fall of communism throughout Eastem Europe and the former Soviet Union created widespread hopes for a rapid transition to political democracy and market economies. Most of the early public and professional debate focused on macroeconomic stabilization and privatization. Financial policies and banking reform received much less attention, partly because macroeconomic stabilization was considered a priority, partly because the subject is hard for the general public to understand, and partly because the institutions of Eastern Europe have been studied less than other aspects of economics. In addition, financial reform exposes a number of unresolved issues -- the resolution of bad debts, corporate finance, and governance in transition -- that were not extensively analyzed at the beginning of the transition process (Fischer 1990; Fischer and Gelb 1990).

With benefit of three years of experience, it is has become clear that financial institutions and instruments play a critical role in the rapid growth of the new private sector and the privatization of large enterprises. It is also clear that the reform process may take longer than expected. Without access to adequate credit, investment capital, and convertible currency, few entrepreneurs can start sound, sizable businesses. This situation also makes it difficult to change large state enterprises into profitable private firms.

Experience with the stabilization process in Eastern Europe suggests that the finarcial and banking sectors are one of the weakest links in the institutional infrastructure of these economies (Bruno 1992). Because of the legacy of central planning, the finaricial systems in these countries are even less developed than in many developing countries. 
Besides slowing the transition to market economies, underdeveloped financial systems undermine political demo racy. Problems such as lack of credit for the new private sector, banking scandals, financial legislation inconsistent with market principles, negative interest rates, and high inflation affect living standards and generate popular discontent, as can be seen in several Eastern European countries and the former Soviet Union.

This paper reviews several issues that are important for reforming the financial sector in transitional economies and provides direction for the future. It includes an overview of the legacy of the communist financial system and recent developments. It also discusses some political aspects of the financial reforms and recent approaches and problems facing many transitional economies.

\section{Legacy of the Communist Financial System}

In many industrialized countries the central bank is responsible for executing monetary policies and fo: regulating and supervising commercial banks. Commercial banks and other financial intermediaries provide services that enhance economic growth and efficiency, such as mobilizing savings, screening and monitoring borrowers, providing and facilitating payment transactions, and providing insurance and risk management. Many western nations have experienced problems in their financial sectors in the last two decades (World Deveiopment Report 1989), but problems in the transition economies are on a much larger scale. 
Financial systems in socialist teconomies lack such basic functions as an efficient payment mechanisrn, financial intermediation between households and businesses, government regulation and supervision (including deposit insurance), and information on creditworthiness. In the past, the socialist economies relied on a monobank system subordinated to the central planning agencies. Co.npetition was virtually nonexistent and is still limited. For these transitional economies to achieve a banking system compatible with a modenı market economy, replacement, rather than reform, is necessary.

In a market economy money is used as a unit of account, a means of payment, and a store of value. In a socialist tconomy, however, its uses are restricted (Aslund 1992). For example, in the former Soviet Union there was no single generally acceptable means of payment. Money was separated into two isolated markets. Households received cash as wages and payments for goods, while the enterprises' account money (non-cash) could be used only among enterprises. Cash deposits made by enterprises could not be legally withdrawn in cash, except to pay wages (Lipton and Sachs 1992). The banking system did not allow depositors to withdraw cash -- the most basic function in a market economy. These practices continue in most states of the former Soviet Union.

In contrast to the fractional-reserve system of market economies, in which the central bank executes monetary policy through such instruments as open market operations, the socialist economies attempted to control monetary and credit policies directly. Instead of :sing discount rates, selling government securities, or changing the reserve requirements of commercial banks to reduce or stimulate demand for credit and investment and to control 
inflation and economic growth, the Soviet central bank simply revised investment credits to bring them in line with the investment spending targets dictated by central planning.

Thus the Soviet banking system was essentially an extension of the government (Chumachenko 1993). There was no real commercial banking system as understood in the West and private banking was prohibited. The state bank and its subsidiaries held a monopoly and were subordinated to the central government. The state bank acted both as a central banker, monitoring monetary and credit aggregates, and as a commercial bank network, providing enterprises with working and investment capital and offering irdividual savings accounts.

Household savings were used for housing loans, while surpluses were passed to the central bank for allocation to enterprises according to centrally determined production targets. The banks did not evaluate or monitor the enterprises' performance or creditworthiness, and losses were routinely covered by the state budget. Each enterprise was assigned a branch of the monobank, so there was no competition among the banks -- just as there was no competition among suppliers throughout the economy (Balcerowicz 1993). Firms were not concerned with profitability, interest rates, or creditworthiness, thus monetary and credit policies did not play an independent role. Banking functions were passive, limited to accounting supervision to ensure that firms were fulfilling their plans. Interest rates were typically low or negative for both deposits and loans.

Hungary, Poland, and Yugoslavia had other financial institutions including foreign trade banks, savings banks, and cooperative banks for farmers. Although they had some 
independence in serving the needs of highly specialized clients, ultimately they were subordinated to the monobank.

Financial accounting stondards in socialist economies did not conform to principles of a market economy and there was no independent auditing of banks and enterprises. The legislation concerning central and commercial banking activities and enterprises was generally inconsistent with market economy principles, and the system of payments was inefficient.

Although the central planning mechanism performed relatively well in the early stages of development by emphasizing heavy and basis industries, it started to break down when economies became more diversified. Widespread shortages of consumer goods, repressed inflation, low quality goods and services, and long queues became common.

In the 1970 s some Eastern European countries began experimenting with limited market reforms by introducing several changes in their banking systems to improve the allocation of resources and accelerate economic growth. In 1971, Yugoslavia was the first to break up the monobank into a central bank and commercial banks. The central banking system consisted of the National Bank of Yugoslavia and a regional branch located in each of the eight republics. The New Economic Mechanism introduced in Hungary in 1968 increased the influence of market forces and of financial and banking instruments on enterprise behavior. In 1987, Hungary broke up the Hungarian National Bank into five commercial state-owned banks. In the same year the Soviet Gosbank was split into a central bank and agricultural, industrial, and savings banks (Conway 1993). Poland created nine 
commercial banks by breaking up its monobank system in 1989. Numerous regional banks were created in Bulgaria in 1987, and two regional banks in Czechoslovakia in 1990.

Although these changes were important, they were insufficient to adequately imprc ve the allocation of resources and address the problems of indebtedness, lack of financial discipline, and inflation. In mosi :aisition economies the banks are still owned by the central bank, the state or the enterprises themselves. In the former Yugoslavia commercial banks are owned by social (self-managed) enternrises. In Bulgaria, Hungary, and the former Scviet Union state enterprises still own a substantial part of bank shares. Competition is still restricred because of regional or functional specialization. For example, nine commercial banks in Poland are regionally based, and there are regional banking monopolies in the former Yugoslavia. In Hungary the bariks were divided along sectoral lines. Ukraine recently introduced regional bank monopolies owned by state enterprises and local government (Pleskovic 1993).

The economic reform programs introduced in Yugoslavia (1989), Poland (1990), Czechoslovakia (1991), and Russia (1992) included additional reforms in the banking sector. For the first time the banking system was involved not only in monetary policy but also in serving the private sector. These reforms covered the liberalization $c^{f}$ interest rates, the introduction of bankruptcy procedures, the privatization of banks, and new banking and financial legislation following the universal banking model.

Although some banking reforms have been introduced in all the tansition economies, these changes have not yet produced a more efficient allocation of resources. Unresolved and difficult problems remain, including inefficient payment systems, deteriorating bank 
portfolios (bad debts, interenterprise credits), lack of competition, inappropriate ownership structures, and inadequaie mechanisms for regulation and supervision.

\section{Political Aspects of Financial Reforms}

In addition to the well-recognized economic problems, the slow pace of financial refor 1 in transition economies creates political difficulties. These range from banking scandals to the slow development of the private sector because of limited credit availability. For example, the first president of the Polish central bank was removed in 1991 in the wake of scandals in the financial system (Slay 1992), and a series of regioral financial scandals have created resentment among Polish voters. Applcbaum (1993) reports that the word "thieves" was scrawled on election posters put up by free-market parties in the last election. In Hungary, forty-two investigations of bank corruption cases are under way (RFE 1993).

Monetary policy is generally used to control inflation in Western economies. In the former Soviet Union lack of appropriate institutional arrangements and other fiscal and monetary diffic $d$ lties have led to very $h . g h$ inflation. High inflation, more than any other factor (Sachs 1993a), has demoralized Russian society and put the overall reform program -and democracy -- at risk. In Russia and the Ukraine, inflation is running at 20 to 30 percent a month, caysing widespread distress. Because inflation was repressed in the past, the population has little experience with the hyperinflation well known in post-war Germany or

Japan. Inflation is destructive in a way that is hard to diagnose. Consequently, people blame the reform process, rather than the legacy of inappropriate fiscal and monetary policy. 
Negative interest rates on household deposits and enormous spreads betweeni úeposit and lending rates are another source of dissatisfaction. Negative interest rates reduce living standards through inflation and discourage savings. Lower savings translate into lower investment and weak economic growtu. Because few alternative assets are available, households spend vaiuable time and pay high premiums in purchase foreign currency as a hedge against inflation. Such currency is usually held at home and earns no interest. For example, in 1993 the only savings bank in Russiu, Sberbank, offered 40 percent annual interest rates on demand depisits, while inflation was more than 400 percent (Caprio and Levine 1993). In Belarus, Ge:rgia, and Kazakhstan the savings bank ylays a central role in mobilizing household deposits, and interest rates on both deposits and loans are sharply negative (Cunway 1993). Because of the lack of competition in banking, household savings are channelled to less productive uses, such as currency speculation and other ways to avoid the costs of inflation. These policies have lowered living standards and eroded the value of pensions and savings, raising public dissatisfaction with reform policies.

The most damaging political effect of the financial crisis is the lack of adequate credit for the emerging private sector. Small private entrepreneurs and employees represent the future middle class whose support is essential for the rapid development of cimocratic institutions and free market economies. Without private sector development, democratization will be slowed, political and economic reforms will be reversed, anit populist politicians will advance.

The current financial system in these countries discriminates against the private sector. The state- or enterprise-owned banks inherited a large portfolio of bad loans. For 
the moment, the banking system continues to subsidize economically nonviable firms, because of soft budget constraints. This burden puts increasing stress on public finarices. Because of the lack of bankruptcy procedures and appropriate legislation, litule action can 'se taken against defauling state enterprises. Morcover, banks with a large share of nonperforming loans have often continued lending to bad enterprises in an atternpt to tum nonperforming loans into "good" ones ano to avoid provisioning for their bad loans. Banks have tried to increase their income by engaging in more risky lenoing by widening the spread between lending and deposit rates. The result is that bad loans have crowded out loans to viable new enterprises, misallocating capital and increasing the cost of credit. Commercisl banks have also invested heavily in government securities to lover the risk and incr:ase their liquidity. In this way household savings have been used to firisice the fiscal deficit instead of business investment.

Crowding out the private sector in favor of loans to state enterprises has occuried in countries even further along in the reform process. For example in Polund, only about 526 (out of several hundred thousand) small and medium-size firms were liquidated during 1990 and 1991, but no large state firms or state-owned banks went bankrupt during that time (Slay 1992). In 1989 the growing private sector received only 2.7 percent of total credit (Lipton and Sachs 1990). At the end of 1990 the private sector accounted for about half of total cinployment in Poland, but received less than one-sixth of domestic credit (Eastwood and Durski 1992). Nine commercial banks were responsible for more than 90 percent of the commercial credit in early 1992, of which about 90 percent went to state enterprises.

Similarly, in Bulgaria, credit has been withheld from the sectors that should receive more 
funds, while government and public enterprises, the sectors that should be adjusting, have benefitted from the credit axpansion (Thorne 1992). In Slovenia, the commercial bank (which had a monopoly) charged real interest rates of 20 to 30 percent in 1992, a prohibitive rate for new private enterprises (Pleskovic and Sachs 1994). In the Czech Republic net borrowing by enterprises declined from 6.4 percent of gross domestic product (GDP) in 1991 to 2.9 percent in 1992 and Hungarian firms borrowed 1.6 percent of GDP in 1991, but became net repayers to banks in 1992 (The Economist 1993).

Policymakers and economists in Eastem Europe focus on the large state-owned enterprises, rather than on the development of a new middle class of small- and mediumsized business (Kornai 1990). Ways need to be found to provide such firms with credit and to remove remaining legal barriers.

Because of the shortage of skilled commercial bankers, banks in most of the transitional countries are still dominated by representatives of the old system, who have little experience in commercial banking. Credits go to public enterprises on an ad hoc or political basis through an informal supply network. The new private sector firms are $\mathrm{x} x \mathrm{xluded}$ from these networks. This situation will likely endure as long as property rights are still in flux and most banks are in the public sector.

Regulation of the financial sector is not yet consistent with the principles of a market economy, because of numerous loopholes in the legal system. The lack of financial discipline, prudential regulation, and supervision breeds fraud and abuse, which undermine public confidence. To turn this situation around, regulatory and supervisory mechanisms and corresponding financial institutions must be developed and enforced. 


\section{Recent Approaches and Problems in the Reform of the Financial Sector}

Early in the reform process, it was believed that a western-type stock market would mobilize capital. Stock exchanges were established in most Eastern European countries and in Russia, but have since foundered because of institutional barriers, lack of appropriate legislation, inexperience, and the slowness of privatization. They presentiy have a very limited role, and access to capital and credit is still dominated by the large domestic or foreign commercial banks (Lampe 1992).

In most countries, banks will remain the major source of external funding for new enterprises. New financial intermediaries - mutual funds, private pension funds, and insurance companies -- are needed to complement the commercial banking system, but will develop slowly. At this stage in the transition, banks represent almost the entire financial system in these economies. The need for fundamental reiorms of the banking sector is pressing. Commercial banks are burdened with large portfolios of nonperforming loans and many banks and large state enterprises in these economies are technically insolvent by international accounting standards. Until restructuring of banks and enterprises takes place, retained earnings may have to play larger than expected roles in enterprise financing.

Several problems must be addressed to enlarge the scope of socialist banking systems. The most important issues to be resolved are competition and ownership, financial restructuring (including privatization), improvement in the payment system, and regulation and supervision. Although all of these changes can be introduced simultaneously, financial restructuring of banks and enterprises should receive top priority. 


\section{Competition and Ownership}

COMPETITION. Competition is essential to market economies. Competition in financial markets holds down transaction costs, allocates risk to those most willing to bear it, and sees that investment is carried out by those with the most promising opportunities (World Development Report 1989).

In most transition economies very large banks coexist with very small ones. In Bulgaria the three largest banks hold most of the country's assets, deposits, and capital, while the 67 smaller banks hold a very small share (Thome 1992). In Romania, the Czech Republic, and Slovakia, a few large banks account for more than 60 percent of commercial lending. In Russia and Romania the major savings bank holds over 90 percent of household deposits. With no competing alternatives people cannot hope to obtain a higher retum on their savings, which is usually negative. Slovenia merged its two largest commercial banks in late 1990 into a monopoly bank that controlled more than 90 percent of the domestic market, while 30 smaller banks had less than a 10 percent share. The management at that time explained that a large monopoly bank would improve efficiency. However, efficiency deteriorated because of the lack of financial discipline and ever-higher losses of social enterprises. Three years later, when the bank was close to insolvency, they sought to reverse the situation by breaking up the monopoly.

Another problem is that commercial banks in these countries are highly specialized either by region, sector or activity. In most cases foreign trade banks, savings banks, and cooperatives are both highly concentrated and separate from the commercial banking system. 
In Poland the nine new commercial banks were given loan portfolios of enterprises along regional lines, limiting the ability of enterprises and households to choose among competing banks. The initial break up of the monopoly banking system in Slovenia resulted in several regional banks without branches.

Such high concentration of bank activity creates several problems. It reduces competition among existing banks and postpones improvements in bank efficiency. Competition promotes efficiency because it lowers costs and creates opportunities for enterprises to discover empty niches in the financial market (Stiglitz 1993). It is importa.. for competition to reach all regions and sectors, to allow households and enterprises a free choice. Regional or sectoral specialization of banks prevents such a choice.

Restructuring the banking sector to promote competition and contestability depends on the country's particular circumstances. For example, following the universal banking model, governments may choose to break up monopolistic savings banks and integrate their branches into commercial banks (Gelb and Gray 1991). In countries where one or two large banks dominate the domestic market but where numerous small banks also exist, it may be necessary to break up the major commercial bank, and merge some small ones to create larger banks. It is important to allow new banks to open branches across the country to prevent regional monopolies.

Competition and contestability can also be encouraged by adopting anti-monopoly legislation, licensing, and auditing procedures, and by establishing necessary regulatory and supervisory agencies. Bank reorganization typically requires a high degree of managerial supervision for several years after the reorganızation (Caprio and Levine 1993). Because of 
an acute shortage of bank managers and supervisors in these countries, the number of newly created banks must not exceed the capacity of the institutions that supervise and implement the restructuring process. It might be necessary to raise capital requirements to prevent the proliferation of very small banks and to encourage mergers of an appropriate and efficient size. As Caprio and Summers (1993) note, limiting the number of banks through an increase in capital requirements is one way to increase the franchise value of bank licenses and to encourage prudent and more efficient bank management.

Foreign banks can also be used to improve competition. Stiglitz (1989) finds that when one or two banks dominate domestic banking, restrictions on foreign banks may serve to protect the monopoly rents of those banks. Since the domestic banking sector in most transition economies is far from competitive, some form of foreign banking may improve the allocation of capital. Foreign banks can also transfer experience and skills to improve the quality of financial services and to train local bankers. If, however, foreign banks are given access to the market while existing banks carry a large portfolio of nonperforming loans and cannot compete, governments must closely regulate and supervise the sector to prevent foreign banks from "creaming" the market.

OWNERSHIP. Most banks in transition economies, with the exception of new private banks, are owned directly or indirectly by the government through the ownership of state enterprises. The existing ownership pattern creates a conflict of interest, because it does not separate lenders and borrowers. 
Central bank ownership of commercial banks and the close association between the central bank and state- or enterprise-owned banks hampers the effectiveness of monetary policies and banking supervision, as experienced by Slovenia. Moreover, state ownership of the banking system interferes with the allocation of credit, and in the absence of appropriate regulation, distorts managerial incentives.

When a few large enterprises control the majority of the banking sector, bank lencing is biased toward those enterprises. Control of credit by enterprises can also be used to preserve the high profit margins of monopolistic enterprises and to discourage enterprise competition. In the former Yugoslavia enterprise ownership of banks led to a distinct conflict of interest between creditor and borrower and resulted in such serious consequences as insolvency (Pleskovic and Sachs 1994). Enterprise managers also served on the banks' board of directors. Over time, regional banking monopolies developed, and directors of social enterprises restricted the autonomy of the banks in the allocation of credit. When these enterprises incurred losses, banks had limited means to exert financial discipline -- and their portfolios worsened. This system has led to an inadequate capital structure, a large share of nonperforming loans, and a large spread between deposit and lending rates. Many enterprises cannot service their rapidly accumulated debts, and a number of banks are close to insolvency.

Despite such negative experiences, many state-owned enterprises in Eastem Europe, the former Soviet Union, and Ukraine (Popov 1993) have created new banks. Government policies should aim to discontinue bank ownership by enterprises to speed the restructuring and privatization process and to prevent a conflict of interest. 


\section{Financial Restructuring}

Financial restructuring of commercial banks and enterprises is one of the most difficult tasks facing transition economies -- a task made even harder because many state-owned enterprises are losing money and cannot repay their debt without new bank credits. In most cases these enterprises cannot be closed because of their importance to the overall economy. Closure would create social problems and raise unemployment to a level that could not be supported by the government, given the inherited socialist welfare system. Similarly, nonviable banks cannot be closed down because of their size. Because the corrmercial banks in. erited many non-performing assets (bad debts), their portfolio reflects the state of the enterprises sector. The value of these portfolios is difficult to evaluate because of a deep recession and the loss of traditional markets.

There are few easy solutions to these problems. Debts of state enterprises cannot just be written off, because as long as enterprises and banks are not privatized, the bad debt problem will reappear, as in the former Yugoslavia and Romania (Clifton and Khan 1993). On the other hand, if banks are put under a hard budget constraint or privatized before they are cleaned up and adequately recapitalized, they mav transfer the burden through high spreads to good enterprises or perhaps shut down illiquid (but solvent) companies.' Levine and Scott (1993) suggest maintaining the inherited obligations and assets on balance sheets up to privatization. The remaining enterprise obligations would be written off at the time of privatization and government securities would be issued to banks for the remaining value of 
loan assets. This policy might work best in countries where the banking reforms are least advanced.

Another view hulds that in the early stages of transition all finance should be provided through retained eamings and equity because of inherited risk, moral hazard, and insufficient regulation and supervision (McKinnon 1991). Government should postpone the privati ation of the banking system until restructuring in the real sectors is complete. The problem with this approach, however, is that it leaves the banking system to restructure itself through very high real interest rates, which would be prohibitive for the new private sector and would prolong the transition process.

The most commonly recommended policy options are debt cancellation and debt socialization. Debt cancellation assumes that removing debt will eliminate previous problems and leave the net worth of the government unchanged, since both banks and enterprises are owned by the state. Debt socialization keeps debt obligations on the firms' books, but moves the bad assets off the commercial banks' balance sheets to another institution, such as a "bad debt" bank (Bonin and Mitchell 1992). This policy, like debt cancellation, lowers the book value of the commercial bank's assets and requires the issue of government securities to recapitalize the banks.

Eastern European countries, with the exception of the Czech Republic and Slovenia, have not adopted debt cancellation. The Czech Republic and Slovenia socialized a portion of the debt by creating specialized (bad debt bank) institutions. Hungary, Poland, and Bulgaria chose a third option: decentralized bank manageinent. According to this policy, provisions against bad loans are accumulated to meet capital requirements. Banks are encouraged to 
obtain repayment, either through debt workouts or through bankruptcy procedures. This policy assumes that commercial banks have sufficient information to determine the viability of their debtors and that this strategy will lower the fiscal burden. This policy could force profitable companies to carry the burden of restructuring through higher costs of bank services. A model developed by Bonin and Mitchell (1992) which contrasts debt cancellation and decentralized bank management policies shows that under reasonable assumptions of capital-market imperfections, canceling inherited debt does not necessarily preserve the net worth of government assets. The managers may, however, be able to appropriate substantial assets through spontaneous privatization after the debt has been canceled.

A still different approach was proposed for Bulgaria by Thome (1993). One group of banks would be privatized quickly and would lend only to private enterprises. The remaining banks would continue under state conirol and would be responsible for restructuring unprofitable state enterprises. This solution was proposed to encourage development of new private enterprises by providing them easy access to credit. A potential problem with this policy is that the incentives guiding the managers of the private banks would differ substantially from those of the state banks, causing difficulties in regulation and supervision.

Although approaches differ from country to country, success depends on the availability of skills and on circumstances. Countries with advanced banking and enterprise reforms can better distinguish between good and bad debts and exert more financial discipline on banks and enterprises.

In general, the experience in Eastern Europe shows that financial restructuring should start early and that both banking reforms and restructuring (e.g., strengthening supervision 
and payments, debt classification and workouts) and enterprise restructuring should take place simultaneously. ${ }^{2}$ Because the problems of indebtedness in banks and enterprises are connected, financial restructuring should include generalized debt-equity swaps between banks and heavily indebted enterprises to reduce the cash flow devoted to debt service payments. ${ }^{3}$ Such a program should divide enterprises into three categories: those to be restructured and subsequently privatized, those to be closed down, and those (public utilities) to be regulated (Pleskovic and Sachs 1994). The debts of heavily indebted enterprises should be reduced before or as a part of privatization. For the enterprises to be closed down a clear timetable should be drawn, and explicit subsidies provided to reduce employment gradually when immediate closure is not feasible. For the remaining public enterprises and utilities, the government should establish regulations, and restructure these enterprises into commercial public, services. These measures should help reduce the burden of enterprise debts on the bank's portfolios and speed privatization. Bank portfolios should be cleared up before their privatization, and government securities should be issued to recapitalize banks. Commercial banks should be involved in the process of enterprise classification, restructuring, and supervision.

Long-term solutions to financial restructuring of banks and enterprises depend on the progress of economic reform, including macroeconomic stabilization, trade reorientation, and privatization. Special attention should be paid to providing small private enterprises with access to credit. It may be necessary for the government to encourage the establishment of financial institutions to service small private businesses and to introduce temporary quotas for commercial banks to lend to the private sector. 


\section{Systems of Payment}

The system of payments in most transitional economies is inefficient. In Russia it takes several weeks to clear checks between banks in Moscow and several months to clear checks from a bank outside of Moscow (Lipton and Sachs 1992). Inefficient payment mechanisms led to the breakdown of the settlement process among the banks, resulting in long delays in clearing of payments and a spread of illiquidity to otherwise healthy enterprises (Sachs 1993b). In Bulgaria, the use of cash by individuals and enterprises as the primary means of payment led to the accumulation of large unsettled balances between banks (Thorne 1993). The underdeveloped payment system was responsible for abuses in the former Yugoslavia and Poland, where a slow interbank check clearing system undermined confidence in the financial system.

An efficient system of payments -- the backbone of a market economy -- should be a top priority for central banks in transitional economies. Whether organized by private or public institutions, the goal should be to clear checks in a few days and thereby instill public confidence in economic transactions.

\section{Concluding Remarks}

The major goal in reforming the financial system in transitional economies should be to change it from a passive to an active participant -- the role it plays in market economies. The banking system must, above all, allocate credit efficientiy. Commercial banks should 
screen borrowers and monitor and discipline enterprises; the government or central bank should regulate and supervise only.

Most transitional economies have adopted a gradual approach to reform of their financial system, maintaining a passive banking role. But Eastern Europe banking reform cannot wait for enterprise restructuring and privatization, because both state enterprises and banks are burdened with inherited bad debts that endanger their solvency and the economic situation as a whole. Financial restructuring of banks and enterprises should be undertakun simultaneously, starting early in the transition process. Commercial banks should play an active role in the financial restructuring of enterprises. Government budgets will have to cover no. viable enterprises debts in a transparent manner and fund recapitalization of banks after clean up. Otherwise the healthy commercial sectors will have to carry the burden of financial restructuring, which will slow the process of transition. In addition to restructuring, improvements in the system of payments, demonopolization of banking, changes in ownership structure (including privatization), and the introduction and implementation of market-based financial legislation need to be addressed early.

The speed of the financial reform in transition economies will depend greatly on the availability of skilled banking professionals, on access to technical assistance from abroad, fiscal constraints, and of course on specific country circumstances. For most countries of the former Soviet Union, for example -- except for the Baltic states -- a prerequisite to successful financial restructuring is macroeconomic stabilization and the reduction of high inflation rates. 
The most important lesson learned from countries that are further along in the reform process is that financial restructuring should start as soon as possible. Delays reduce living standards (burdening the healthy parts of the economy with direct taxes or higher financial costs;, discourage small-scale entrepreneurs, inhibit entry of new firms, and cause the economy to stagnate further. 


\section{Notes}

1. Consequences of covering bank losses with high' spreads on new loans are discussed in the Wurld Development Report 1989.

2. Recapitalization is an important part of financial restructuring. However, there are also many other elements of financial restructuring that are critical. For example, the experience of Slovenia shows that it is important to establish early in the process a Bank Restructuring Agency and Enterprise Restructuring Agency to deal with the classification of enterprises and their debts, workout of bad loais, partial recapitalization of banks and enterprises and other issues of restructuring.

3. Since bad debt means bad equity, as noted by Caprio and Levine (1993), only viable debts should be included. 


\section{References}

Applebaum, Anne. 1993. "Poland's Old Guard Lures Rural Voters." The Financial Times,

September 20, 1993, p.2.

Aslund, Anders. 1992. Post-Communist Economic Revolutions: How Big a Bang? Washington,

D.C.: Center for Strategic and International Studies.

Balcerowicz, Leszek. 1993. "The Direction of Change in the Financial Systems in Central and

Eastern European Countries." Warsaw: Warsaw School of Economics. Mimeo.

Bonin, John and Janet Mitchell. 1992. "Creating Efficient Banks During the Transition: Do Bad

Loans Lead to Bad Policy?" Ithaca, N.Y.: Cornell University. Mimeo.

Bruno, Michael. 1992. "Stabilization and the Macroeconomics of Transition -- How Different is

Eastern Europe?" Washington, D.C.: IMF. Mimeo.

Caprio, Gerard, Jr. and Ross Levine. 1993. "Reforming Finance in Transitional Socialist

Economies." Washington, D.C.: World Bank, Working Paper Series 898.

Caprio, Gerard, Jr. and Lawrence Summers. 1993. "Finance and Its Reform: Beyond Laissez-

Faire." Washington, D.C.: Working Paper Series 1171.

Clifton, Eric V. and Mohsin S. Khan. 1993. "Interenterprise Arrears in Transforming Economies."

IMF Staff Papers, Vol. 40, no. 3.

humachenko, N.G. 1993. "Economic Restructuring of the former Soviet Union: National and

Regional Perspectives. " International Regional Science Review, 15 no.3:235-46.

snway, Patrick. 1993. "The Problem of Intermediation in a Country in Transition: The Example of Sberbanks." Chapel Hill, NC: University of North Carolina Press. Mimeo. 
Fischer, Stanley. 1990. "Comment on: Creating a Market Economy in Eastern Europe: The Case of Poland." by Lipton and Sachs. Brookings Papers on Economic Activity 1, pp. 75-147. Fischer, Stanley and Alan Gelb. 1990. "Issues in Socialist Economic Reform." PRE Working Paper no. 565. Washington, D.C.: World Bank. stwood, Robert and Adam Durski. 1992. "Financial Reform in Poland: Some Parallels with Chilean Experience 1973-1983." Paper prepared for the conference on Macroeconomic Stabilization of the Polish Economy, Warsaw, June 5-6.

lb, H. Alan, and Cheryl W. Gray. 1991. "The Transformation of Economies in Central and Eastern Europe." Policy Research Series no 17. Washington, D.C.: World Bank. mai, Janos. 1990. "Comment on: Creating a Market Economy in Eastern Europe: The Case of Poland." by Lipton and Sachs. Brookings Paper on Economic Activity 1, pp. 75-147. npe, John R. ed. 1992. Creating Capital Markets in Eastern Europe. Washington, D.C.: The Woodrow Wilson Center Press.

Levine, Ross, and David Scott. 1993. "Old Debts and New Begirnings: A Policy Choice in Transitional Socialist Economies." World Develojment. Vol. 21, No.3, pp 319-330. ton, David and Jeffrey Sachs. 1990. "Creating a Market Economy in Eastern Europe: The Case of Poland." Brookings Papers on Economic Activity, 1, pp. 75-147. on, David and Jeffrey Sachs. 1992. "Russia: Towards a Market-Based Monetary System." Central Banking. Volume III, number 1. McKinnon, Ronald I. 1991. The Order of Economic Liberalization: Financial Control in the Transition to a Market Economy. Baltimore, MD: Johns Hopkins University Press. 
Pleskovic, Boris. 1993. "Regional Development and Transition in the former Soviet Union: A Comment. " International Regional Science Review, 15, no. 3: 297-305.

Pleskovic, Boris and Jeffrey Sachs. 1994. "Political Lıdependence and Economic Reform in Slovenia." The Transition in Eastern Europe, eds. C. Blanchard, K. Froot, and J. Sachs. Chicago: NBER and University of Chicago Press, pp. 191-230.

Popov, M.I. 1993. "Self-financing Regional Partnerships for Economic Restructuring in the former Soviet Union." International Regional Science Review. 15, no 3:281-89.

Radio Free Europe/Radio Liberty (RFE/RL). 1993. "Hungarian Bank Corruption Investigation Under Way." No. 176, September 14.

Sachs, Jeffrey. 1993a. "The Road to the Market." Washington Post. March 28, p. C2.

Sachs, Jeffrey. 1993b. "Prospects for Monetary Stabilization in Russia." Stockholm: Prepared for the Conference on Economic Transformation in Russia, Stockholm School of Economics, June.

Slay, Ben. 1992. "The Banking Crisis and Economic Reform in Poland." RFE/RL Research Report, Vol. 1, no. 23, June, pp. 33-40.

Stiglitz, Joseph E. 1989. "Financial Markets and Development." Oxford Review of Economic Policy. Vol 5, no. 4. . 1993. "The Role of the State in Financial Markets." in Procedings of the World Bank Annual Conference on Development Economics 1993 eds. M. Bruno and B. Pleskovic. Washington, D.C.: World Bank.

The Economist. 1993. "One little piggy went to market-but starved." November, pp. 83-84. 
Thome, Alfredo. 1992. "Reforming Financial Systems in Eastern Europe: The Case of Bulgaria." In Creating Capital Markets in Eastern Europe, J.R. Lampe, ed. Washington, DC: The Woodrow Wilson Center Press.

World Development Report. 1989. Washington, D.C.: World Bank. 


\section{Pollcy Research Working Paper Serles}

Title

WPS1221 Does Research and Development Contribute to Economic Growth in Developing Countries?

WPS1222 Trade Reform in Ten Sub-Saharan Countries: Achievements and Failures

W'j1223 How Robust is a Poverty Profile?

WPS1224 Devaluation in Low-Inflation Economies

WPS1225 Intra-Sub-Saharan African Trade: Is It Too Little?

WPS1226 Forecasting Volatility in Commodity Markets

WPS1227 Designing Water Institutions: Market Failures and Institutional Response

WPS1228 Competition, Competition Policy. and the GATT

WPS1229 The Structure, Regulation, and Performance of Ponsion Funds in Nine Industrial Countries

WPS1230 Unemployment in Mexico: its Characteristics and Determinants

WPS1231 Making a Market: Mass Privatization in the Czech and Slovak Republics

WPS1232 Will GATT Entorcement Control Antidumping?

WPS1233 Hedging Cotton Price Risk in Francophone African Countries
Author

Nancy Birdsall

Changyong Rhee

Faezeh Foroutan

Martin Ravallion

Benu Bidani

Miguel A. Kiguel

Nita Ghei

Faezeh Foroutan

Lant Pritchett

Kenneth F. Kroner

Devin P. Kineatsey

Stijn Claessens

Marie Leigh Livingston

Sernard M. Hoekman

Petros C. Mavroidis

E. P. Davis

Ana Revenga

Michelle Riboud

Nemat Shafik

J. Michael Finger

K. C. Fing

Sudhakar Satyanarayan

Etton Thigpen

Panos Varangis
Date

November 1993

November 1993

November 1993

November 1993

November 1993

November 1993

December 1993

December 1993

December 1993

December 1993

December 1993

December 1993

December 1993

December 1993

Andrés Solimano and Stabilization Policies in Hungary: An Empirical Analysis
S. Rajan 33747

P. Infante

37642

Contact

for paper

S. Falion 38009

P. Cook 33902

R. Luz 39059

S. Fallon 38009

F. Hatab 35835

C. Spooner 30464

L. O'Connor 37009

(1)

R. Stephen 37040

A. Correa 38549

N. Artis

37947

D. Gustafson 33714

S. Florez 39075 


\section{Pollcy Research Worklng Paper Sorles}

THlo

\begin{abstract}
WPS1235 Eastern Europe's Experience with Banking Reform: Is There a Role for Banks in the Transition?
WPS1236 The Impact of Two-Tier Preducer and Consumer Food Pricing in India
WPS1237 Bank Pertormance and the Impact of Financial Restructuring in a Macroeconomic Framework: A New Application

WPS1238 Kenya: Structural Adjustment in the 1980s

WPS1239 Principles of Regulatory Policy Design

Author

Alfredc Thorne

Date

Contact

for paper

Maurice Schift

Yavuz Boray

Hector Sierra

December 1993

N. Jose

33688

December 1993

S. Falion 38009

December 1993

C. Lim 30864

Gurushri Swamy

January 1994

V. Saldanha 35742

David E. M. Sappington

William Easterly

Paulo Vieira da Cunha

Crisis in Russia, 1992-93

Pablo T. Spiller

Ingo Vogelsang

Commitment in the British

Telecommunications Sector

WPS1242 Financial Policies in Socialist

Countries in Transition
Boris Pleskovic

January 1994

M. Jandu

33103 